\title{
Nilai ketebalan kortikal mandibula pada anak dan remaja terinfeksi HIV
}

\author{
Fadhlil Ulum Abdul Rahman ${ }^{1 *}$, Alongsyah Zulkarnaen Ramadhan', \\ Farina Pramanik ${ }^{2}$, Ria Noerianingsih Firman ${ }^{2}$
}

\begin{abstract}
Objectives: The aim of this study was to obtain the value of mandibular cortical thickness in HIVinfected children and adolescents based on panoramic radiographs.

Material and Methods: This descriptive and crosssectional study was carried out on 43 panoramic radiographs of HIV-infected children and adolescents. The value of mandibular cortical thickness were measured by three indices regarded as mental index (MI), gonial index (GI), and antegonial index (AGI) using a digital calipers directly on the panoramic radiographs which had been taken previously.
\end{abstract}

Results: Among 43 panoramic radiographs, 18 (41,86\%) were boys and 25 (58,14\%) were girls. Based on age range, there are 30 samples $(69,77 \%)$ were categorized as children with age range 5-11 years and 13 samples $(30,23 \%)$ were categorized as adolescents with age range 12-16 years. The lower value of mandibular cortical thickness based on MI, AGI, and AGI was seen in girls compared to boys. The adolescents have a higher value of mandibular cortical thickness compared with the children.

Conclusion: There are different values of mandibular cortical thickness in HIV-infected children and adolescents based on sex and age.

Keywords: Antegonial index, gonial index, HIV, mandibular cortical index, mental index

Cite this article: Rahman FUA, Ramadhan AZ, Pramanik F, Firman RN. Nilai ketebalan kortikal mandibula pada anak dan remaja terinfeksi HIV. Jurnal Radiologi Dentomaksilofasial Indonesia 2019;3(3)1-4. https://doi.org/10.32793/ jrdi.v3i3.437

\section{PENDAHULUAN}

Pada tahun 2017 sebanyak 180.000 anak berusia 0-14 tahun menjadi penderita baru di antara 1,8 juta anak-anak dengan infeksi HIV di seluruh dunia. Secara global, peningkatan penderita baru infeksi HIV juga terlihat pada remaja usia 10-19 tahun dengan peningkatan $30 \%$ mencapai angka 2,1 juta dari tahun 2005 hingga tahun 2016. ${ }^{1,2}$ Data tersebut menunjukkan peningkatan signifikan jumlah penderita infeksi HIV pada anak-anak dan remaja.

HIV adalah virus yang bereplikasi pada limofsit $T$ CD4+ dan monosit/makrofag yang menginduksi terjadi penurunan yang ekstrim pada sistem imunitas tubuh manusia. Lebih lanjut, infeksi HIV dapat memengaruhi jaringan, organ, dan sistem organ lainnya seperti ginjal, hepar, sistem saraf pusat, jantung, bahkan tulang dengan karakteristik patogenesis yang kompleks. ${ }^{3}$

Perubahan pada tulang telah banyak diamati pada perjalanan penyakit infeksi HIV sejak hampir dua decade terakhir. Secara umum, nilai bone mineral density (BMD) merupakan lesi tulang yang paling sering ditemukan pada pasien dengan infeksi HIV. Sejumlah penelitian cross-sectional telah mendokumentasikan nilai BMD yang lebih rendah pada orang-orang yang terinfeksi HIV dibandingkan dengan kelompok kontrol yang tidak terinfeksi. ${ }^{4}$ Adapun pathogenesis penurunan nilai BMD pada pasien terinfeksi HIV sangat mungkin bersifat multifaktorial. ${ }^{5}$
Pada beberapa penelitian terbaru, osteoporosis disebutkan telah tampak sebagai pemicu comorbidity atau kecacatan yang signifikan pada pasien terinfeksi HIV. Nilai BMD yang rendah pada pasien terinfeksi HIV menjadi potensi terbesar peningkatan risiko fraktur pada tulang. Menurut Compston pada tahun 2015, selain faktor risiko klasik fraktur tulang, faktor spesifik yang terkait dengan infeksi HIV juga mungkin dapat berkontribusi termasuk penggunaan obat-obatan dalam terapi antiretrovirus. Peningkatan risiko osteoporosis dan fraktur pada orang dewasa yang terinfeksi HIV telah dilaporkan dalam banyak literatur. Pada anak-anak dan remaja dengan infeksi HIV, kondisi kesehatan tulang secara umum juga tampak terganggu, namun konsekuensi jangka panjangnya sebagian besar tidak jelas dan belum banyak dilaporkan. ${ }^{6}$

Nilai bone mineral density (BMD) adalah jumlah jaringan tulang dalam suatu volume tulang tertentu. ${ }^{7}$ Metode pengukuran nilai BMD yang telah dijadikan golden standard adalah dengan menggunakan pemeriksaan Dual Energy X-Ray Absorption (DXA/DEXA). Metode ini mengukur kepadatan tulang langsung pada jaringan tulang seperti tulang vertebra, femur, dan tulang lengan bawah dengan akurasi yang tinggi. ${ }^{8,9}$ Walaupun metode DXA adalah suatu pemeriksaan yang terstandardisasi dan ideal untuk memperoleh nilai 
BMD pada pasien, metode ini juga memiliki beberapa kelamahan seperti membutuhkan peralatan dan operasional yang mahal, membutuhkan teknisi yang terlatih, tidak bersifat portable, dan kurang praktis dalam penggunaan rutin sehari-hari. ${ }^{10}$ Kemudian pada tahun 1993, penilaian BMD pada tulang rahang diperkenalkan Penilaian BMD rahang dapat dianggap berguna, bahkan sangat perlu, dalam beberapa situasi klinis seperti keterlibatan penyakit mulut dan/atau penyakit sistemik lainnya, perencanaan perawatan seperti implant berikut evaluasi terapi dan tindakan tindak lanjutnya. ${ }^{7}$ Nilai BMD pada rahang dapat menggambarkan kuantitas dan kualitas tulang pada rahang yang terkait dengan beberapa kondisi tertentu.

Radiograf panoramik memiliki riwayat yang panjang dan telah sangat luas digunkan untuk memeriksa keseluruhan kondisi gigi geligi, sendi temporomandibula, tulang rahang, serta jaringan sekitarnya. Berdasarkan penelitian terkini, teknik ini juga dilaporkan memiliki peran yang sangat penting bagi dokter gigi dalam identifikasi dan evaluasi pasien dengan kecenderungan osteoporosis atau yang memiliki nilai densitas tulang yang rendah. ${ }^{11,12}$

Penggunaan radiograf panoramik sebagai alat atau metode screening dipertimbangkan untuk menilai bone mineral density karena bersifat costeffective dan tersedia secara rutin, walapun idealnya memerlukan konfirmasi lebih lanjut dengan DXA dan marker biomekanik. ${ }^{13}$ Sama dengan metode DXA, radiograf panoramik dapat digunakan untuk menganalisis rendahnya nilai BMD pada rahang yang terkait dengan beberapa kondisi, termasuk kondisi infeksi HIV. Beberapa indeks pengukuran yang sering digunakan untuk memprediksi nilai BMD yang rendah pada pasien dengan kondisi tertentu seperti mandibular cortical index $(\mathrm{MCl})$, panoramic mandibular index (PMI), mentale index (MI), antegonial index (AGI), dan gonial index (GI). ${ }^{14}$ Indeks tersebut telah reliable dalam pengukuran dan penilaian kualitas tulang pada mandibula terkait prediksi nilai BMD yang rendah.

Penelitian ini bertujuan untuk memperoleh nila ketebalan kortikal mandibula pada anak dan remaja terinfeksi HIV berdasarkan radiograf panoramik sebagai screening tools menggunakan tiga indeks yaitu $\mathrm{MI}, \mathrm{AGI}$, dan $\mathrm{Gl}$.

\section{BAHAN DAN METODE}

Penelitian ini merupakan penelitian deskriptif cross-sectional dengan menggunakan 43 radiograf panoramik pasien anak dan remaja terinfeksi HIV dengan kisaran usia antara 5 sampai 16 tahun dari salah satu pusat laboratorium diagnostik swasta di Bandung, Jawa Barat. Pemeriksaan radiografi panoramik dilakukan berdasarkan rujukan dari Departemen Ilmu Penyakit Mulut Rumah Sakit Gigi dan Mulut Universitas Padjadjaran Bandung sebagai data pendukung untuk melengkapi catatan rekam medis pasien anak dan remaja terinfeksi HIV tersebut. Nilai ketebalan kortikal mandibula diukur dengan tiga indeks yang dipilih yaitu $\mathrm{MI}, \mathrm{AGI}$, dan $\mathrm{G}$ menggunakan kaliper digital langsung pada radiograf panoramik yang telah diperoleh sebelumnya. Mental Index (MI) (Gambar 1) adalah pengukuran ketebalan kortikal mandibula yang dinilai menggunakan teknik yang diperkenalkan oleh Ledgerton et al., dengan cara suatu garis diproyeksikan melewati secara tegak lurus terhadap garis singgung ke batas bawah mandibula tepat di tengah foramen mentalis. Secara umum nila normal dari $\mathrm{Ml}$ adalah lebih besar dari $3,1 \mathrm{~mm} .{ }^{14,15}$

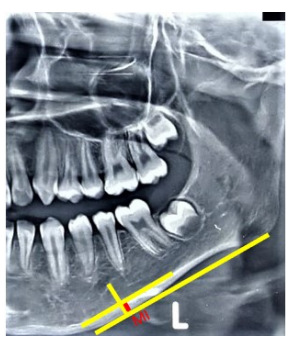

Gambar 1. Mental Index (MI); hasil pengukuran MI dalam satuan millimeter $(\mathrm{mm})$

Gonial Index (GI) (Gambar 2) adalah pengukuran ketebalan kortikal mandibula pada sudut bisektris antara garis singgung yang dibuat pada batas posterior ramus mandibula dan batas paling inferior mandibula. Nilai normal dari GI adalah lebih besar dari $1,2 \mathrm{~mm}^{14}$

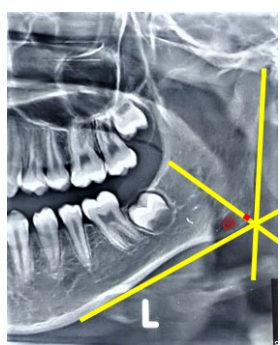

Gambar 2. Gonial Index (GI); hasil pengukuran $\mathrm{Gl}$ dalam satuan millimeter (mm)

Antegonial Index (AGI) (Gambar 3) adalah pengukuran ketebalan kortikal mandibula yang diukur pada garis tegak lurus terhadap kortikal mandibula pada persimpangan dengan garis singgung yang dibuat ke batas anterior ramus mandibula. Nilai normal dari AGI adalah lebih besar dari $3,2 \mathrm{~mm}^{14}$

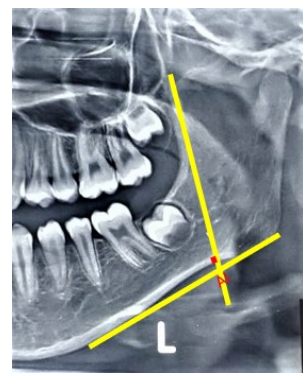

Gambar 3. Antegonial Index (AGI); hasil pengukuran AGI dalam satuan millimeter $(\mathrm{mm})$

Nilai ketebalan mandibula kortikal dalam tiga indeks ini diukur pada sisi kanan dan kiri mandibula 
karena di sisi yang berbeda mungkin dipengaruhi oleh kekuatan oklusal yang berbeda, lalu kemudian dirata-ratakan.

\section{HASIL}

Di antara 43 radiografi panoramik, $18(41,86 \%)$ diantaranya adalah laki-laki dan 25 (58,14\%) adalah perempuan. Berdasarkan rentang usia, terdapat 30 sampel $(69,77 \%)$ yang dikategorikan sebagai anakanak dengan rentang usia 5-11 tahun dan 13 sampel (30,23\%) dikategorikan sebagai remaja dengan rentang usia 12-16 tahun. Kategori umur ini dikeluarkan oleh WHO.

Skor MI yang lebih rendah diamati pada anak perempuan $(9,52 \pm 2,10$ pada mandibula kiri, $9,57 \pm$ 2,32 pada mandibula kanan) dibandingkan anak lak -laki (11,24 $\pm 3,52$ pada mandibula kiri, 11,26 $\pm 3,04$ pada mandibula kanan/tabel 1). Untuk kelompok umur, skor $\mathrm{MI}$ lebih rendah pada anak-anak dibandingkan pada umur remaja $(8,95 \pm 1,72$ pada mandibula kiri, 9,02 $\pm 1,81$ pada mandibula kanan (tabel 2).

Nilai pengukuran $\mathrm{Gl}$ pada anak perempuan menunjukkan skor yang lebih rendah $(1,24 \pm 0,53 \mathrm{di}$ mandibula kiri, 1,34 $\pm 0,53$ di mandibula kanan) dibandingkan pada anak laki-laki $(1,44 \pm 0,51 \mathrm{di}$ mandibula kiri, $1,46 \pm 0,41)$. Untuk kelompok usia, skor GI pada anak-anak umumnya lebih rendah daripada kelompok remaja (tabel 3 dan 4)

Nilai pengukuran indeks AGI pada anak perempuan menunjukkan skor yang lebih rendah $(2,58 \pm 0,80$ di mandibula kiri, 2,48 $\pm 0,67$ di mandibula kanan) dibandingkan pada anak laki-laki $(2,79 \pm 0,56$ di mandibula kiri, $2,82 \pm 0,71)$. Untuk kelompok usia, skor AGI pada anak-anak umumnya lebih rendah daripada kelompok remaja (tabel 5 dan 6).

\section{DISKUSI}

Menurut Giovani et al. (2017), nilai BMD yang rendah dan penurunan massa tulang telah dilaporkan pada pria dan wanita yang terinfeksi HIV, serta pada anak-anak dan remaja. ${ }^{16}$ Pengukuran ketebalan kortikal mandibula dalam penelitian ini menggambarkan kondisi kortikal mandibula pada pasien anak dan remaja terinfeks HIV berdasarkan tiga indeks yang dapat menggambarkan prediksi nilai BMD.

Nayyar et al. (2017) menyatakan bahwa korteks mandibula adalah suatu area luas yang dipengaruhi oleh berbagai perubahan pada masa perkembangan, patologis, fisiologis, dan dapat

\begin{tabular}{lllllll}
\hline & $\mathbf{N}$ & MI & Min & Max & Mean & SD \\
\hline Perempuan & 25 & Kiri & 4.16 & 14.46 & 9.52 & 2.10 \\
& & Kanan & 4.34 & 15.15 & 9.57 & 2.32 \\
\hline Laki-Laki & \multirow{2}{*}{18} & Kiri & 6.47 & 21.61 & 11.24 & 3.52 \\
& & Kanan & 6.53 & 19.36 & 11.26 & 3.04
\end{tabular}

Tabel 1. Hasil pengukuran ketebalan kortikal mandibula dengan indeks MI pada sampel laki-laki dan perempuan

\begin{tabular}{lllllll}
\hline & $\mathbf{N}$ & MI & Min & Max & Mean & SD \\
\hline $\begin{array}{l}\text { Anak-anak } \\
\text { (5-11 tahun) }\end{array}$ & \multirow{2}{*}{30} & Kiri & 4.16 & 12.90 & 9.16 & 1.72 \\
& & Kanan & 4.34 & 11.77 & 9.41 & 1.81 \\
\hline $\begin{array}{l}\text { Remaja (12- } \\
\text { 16 tahun) }\end{array}$ & \multirow{2}{*}{13} & Kiri & 10.41 & 21.61 & 13.20 & 2.85 \\
& & Kanan & 10.85 & 19.36 & 13.17 & 2.31 \\
\hline
\end{tabular}

Tabel 2. Hasil pengukuran ketebalan kortikal mandibula dengan indeks MI pada sampel laki-laki dan perempuan

\begin{tabular}{lllllll}
\hline & $\mathbf{N}$ & MI & Min & Max & Mean & SD \\
\hline Perempuan & 25 & Kiri & 0.05 & 2.36 & 1.24 & 0.53 \\
& & Kanan & 0.15 & 2.40 & 1.34 & 0.53 \\
\hline Laki-Laki & \multirow{2}{*}{18} & Kiri & 0.67 & 2.31 & 1.44 & 0.51 \\
& & Kanan & 0.85 & 2.12 & 1.46 & 0.41 \\
\hline
\end{tabular}

Tabel 3. Hasil pengukuran ketebalan kortikal mandibula dengan indeks $\mathrm{Gl}$ pada sampel laki -laki dan perempuan

\begin{tabular}{lllllll}
\hline & $\mathbf{N}$ & MI & Min & Max & Mean & SD \\
\hline Anak-anak & \multirow{2}{*}{30} & Kiri Kanan & 0.05 & 2.36 & 1.20 & 2.10 \\
(5-11 tahun) & & & 0.15 & 2.40 & 1.28 & 2.32 \\
\hline Remaja (12- & \multirow{2}{*}{13} & Kiri & 1.19 & 2.31 & 1.62 & 3.52 \\
16 tahun) & & Kanan & 1.06 & 2.12 & 1.63 & 3.04 \\
\hline
\end{tabular}

Tabel 4. Hasil pengukuran ketebalan kortikal mandibula dengan indeks GI pada sampel rentang usia anak dan remaja

\begin{tabular}{lllllll}
\hline & $\mathbf{N}$ & MI & Min & Max & Mean & SD \\
\hline Perempuan & 25 & Kiri & 0.37 & 4.11 & 2.58 & 0.80 \\
& & Kanan & 0.26 & 3.61 & 2.48 & 0.67 \\
\hline Laki-Laki & \multirow{2}{*}{18} & Kiri & 2.12 & 4.04 & 2.79 & 0.56 \\
& & Kanan & 1.68 & 4.33 & 2.82 & 0.71 \\
\hline
\end{tabular}

Tabel 5. Hasil pengukuran ketebalan kortikal mandibula dengan indeks AGI pada sampe laki-laki dan perempuan

\begin{tabular}{lllllll}
\hline & $\mathbf{N}$ & MI & Min & Max & Mean & SD \\
\hline Perempuan & 25 & Kiri & 0.37 & 4.11 & 2.58 & 0.80 \\
& & Kanan & 0.26 & 3.61 & 2.48 & 0.67 \\
\hline Laki-Laki & \multirow{2}{*}{18} & Kiri & 2.12 & 4.04 & 2.79 & 0.56 \\
& & Kanan & 1.68 & 4.33 & 2.82 & 0.71 \\
\hline
\end{tabular}

Tabel 6. Hasil pengukuran ketebalan kortikal mandibula dengan indeks AGI pada sampe rentang usia anak dan remaja 
terkait usia. ${ }^{17}$ Penyebab rendahnya nilai BMD dan peningkatan risiko fraktur pada pasien terinfeksi HIV tampaknya multifaktorial, termasuk pada anak dan remaja. Adanya interaksi yang rumit antara dampak infeksi HIV itu sendiri, faktor risiko klasik dari osteoporosis yang diperburuk oleh konsekuensi logis dari adanya keadaan kronis sepert kekurangan gizi atau berat badan rendah, kadar vitamin D rendah, dan faktor terkait terap antiretrovirus. ${ }^{18}$

Secara umum, hasil pengukuran kepadatan tulang mandibula melalui indeks ketebalan kortika menunjukkan ketebalan kortikal mandibula yang rendah pada anak-anak daripada remaja terutama pada anak perempuan. Perbedaan nilai ketebalan kortikal mandibula pada anak dan remaja yang terinfeksi HIV berdasarkan jenis kelamin sejalan dengan penelitian sebelumnya dari Pal dan Amrutesh yang menyatakan bahwa mental index (MI) dipengaruhi oleh jenis kelamin. Laki-laki menunjukkan nilai $\mathrm{Ml}$ yang jauh lebih tingg daripada wanita. ${ }^{19}$ Sedangkan nilai ketebalan kortikal mandibula lebih tinggi pada remaja sejalan dengan hasil penelitian Gomez dan De Lima pada tahun 2008 bahwa tingkat pertumbuhan mandibula terbesar terjadi pada remaja pada puncaknya di masa pubertas. ${ }^{20}$ Pernyataan ini perlu dibuktikan lebih lanjut melalui dengan lebih banyak sampel.

Dalam penelitian ini, nilai ketebalan kortikal mandibula pada anak-anak dan remaja dengan infeksi HIV menunjukkan nilai yang berbeda di tiga indeks yang digunakan. Ada nilai normal yang terkait dengan $\mathrm{MI}, \mathrm{GI}$, dan AGI yang banyak digunakan untuk perbandingan radiomorfometrik. Namun dalam penelitian ini, sampelnya adalah anak -anak dan remaja, nilai normal itu tidak dapat digunakan sebagai perbandingan dengan nilai yang diperoleh sebab terkait masa perkembangan mandibula. Selain itu belum pernah ada patokan nilai normal untuk indeks $\mathrm{MI}, \mathrm{GI}$, dan AGI yang secara khusus menggambarkan keadaan normal dari ketebalan kortikal mandibula pada usia anak anak dan remaja.

Keterbatasan penelitian ini adalah bahwa tidak ada kelompok kontrol untuk membandingkan nila ketebalan kortikal mandibula pada anak-anak yang terinfeksi HIV dan remaja dengan anak-anak dan remaja tanpa infeksi HIV.

\section{SIMPULAN}

Dari hasil penelitian ini disimpulkan bahwa terdapat perbedaan nilai ketebalan tulang kortika mandibula pada anak-anak dan remaja terinfeksi HIV berdasarkan jenis kelamin dan usia. Sebaga saran, penelitian lebih lanjut tentang hal ini menggunakan sampel lebih banyak dan menggunakan kelompok kontrol sehingga dapat diperoleh perbandingan nilai normal yang dapat digunakan secara luas.

\section{DAFTAR PUSTAKA}

1. UNAGIDS DATA 2018. (online) available at https:// www.unaids.org/sites/default/files/media asset/unaids-data2018_en.pdf. Diakses pada tanggal 23 Agustus 2019

2. Slogrove AL, Schomaker M, Davies MA, Williams P, Balkan $S$, Ben-Farhat J, et.al. The epidemiology of adolescents living with perinatally acquired HIV: A cross-region global cohort analysis. PLoS Medicine 2018; 15 (3).

3. Levy JA. HIV pathogenesis: 25 years of progress and persistent challenges. AGIDS 2009; 23:147-160.

4. Compston J. HIV infection and osteoporosis. Bonekey Rep 2015; 4:636

5. Borderi M, Gibellini D, Vescini F, De Crignis E, Cimatti L, Biagetti C, et.al. Metabolic bone disease in HIV infection. AGIDS 2009 23 (11): 1297-1310.

6. Eckard AR, Mora S. Bone health in HIV-infected children and adolescents. Curr Opin HIV AGIDS. 2016; 11(3): 294-300.

7. Gulsahi A, Paksoy CS, Ozden S, Kucuk NO, Cebeci ARI, Genc Y. Assesment of bone mineral density in the jaws and its relationship to radiomorphometric indices. Dentomaxillofacial Radiol 2010; 39 (5): 284-289.

8. Yeler DY, Koraltan M, Hocaoglu P, Arslan C, Erselcan T, Yeler H. Bone quality and quantity measurement techniques in dentistry. Cumhuriyet Dental Journal

9. Colon CJP, Vicenty ILM, Rodriguez MF, GA Alejandra, Rivera BP, Gerardo CV, et al. Muscle and bone mass loss in the elderly population: advances in diagnosis and treatment. Journal of Biomedicine 2018; 3: 40-49

10. Nana A, Slater GJ, Stewart AD, Burke LM. Methodology Review: using dual-energy $x$-ray absorptiometry (DXA) for the assessment of body composition in athletes and actives people. International Journal of sport nutrition and exercise metabolism 2014.

11. Dagistan S, Bilge OM. Comparison of antegonial index, mental index, panoramic mandibular index and mandibular cortical index values in the panoramic radiographs of normal males and male patients with osteoprorsis. Dentomaxillofacial Radio 2010; 39 (5):290-294

12. Hardanti S, Azhari, Oscandar F. Description of mandibular bone quality based on measurements of cortical thickness using Mental Index of male and female patients between 40-60 years old. Imaging Sci Dent 2011; 41 (4): 151

13. Balto KA, Gomaa MM, Feteih RM, AlAmoudi NM, Elsamanoudy AZ, Hassanien MA, M Ardawi MS. Dental panoramic radiographic indices as a predictor of osteoporosis in postmenopausal Saudi Women. J Bone Metab 2018: 25 (3):165 $-173$

14. Bajoria AA, ML Asha, Kamath G, Babshet M, Patil P, Sukhija P. Evaluation of radiomorphometric indices in Panoramic Radiograph- a screening tool. The open dentistry journal 2015; 9 (Suppl2:M9): 303-310.

15. Govindraju P, Kumar TSM, Chandra $P$, Balaji $P$, Showbhagya $M B$. 'Panoramic radiomorphometric indices of mandible: biomarker for Osteoporosis', in VR Preedy (ed) Biomarkers in Bone Disease, Biomarkers in Disease: Methods, Discoveries and Application. Dordrecht: Springer, pp.1-10.

16. Giovani EM, Santos CC, Georgevich NR, Noro-Filho GA Caputo BV. Diagnosis of Bone Changes in Mandibles of Aids Patients Who Had Administered Haart and Developed Lipodistrophic Syndrome. Res J Med Med Sci 2017; 4 (5)

17. Nayyar AS, Naphade UM, Naphade MV, Qureshi AQ, Siddiqui FI. Osteoporosis: Current State and need for screening Possible role of oral physicians. Indian Journal of Multidisciplinary Dentistry 2016; 6 (2)

18. McComsey GA, Tebas P, Shane E, Yin MT, Overton ET, Huang IS, et al. Bone disease in HIV infection: a practical review and recommendations for HIV care providers. Clin Infect Dis 2010; 51 (8): 937-946.

19. Pal S, Amrutesh S. Evaluation of panoramic radiomorphometric indices in Indian population. Cumhuriyet Dent J 2013; 16 (4) 273-281.

20. Gomes AS, De Lima EM. Mandibular growth during adolescence. The Angle Orthodontist 2006; 76 (5): 786-790. 